\title{
Policy Lessons From China's CCS Experience
}

Xiaoliang Yang, Wolfgang Heidug and Douglas Cooke 


\section{About KAPSARC}

The King Abdullah Petroleum Studies and Research Center (KAPSARC) is a non-profit global institution dedicated to independent research into energy economics, policy, technology and the environment across all types of energy. KAPSARC's mandate is to advance the understanding of energy challenges and opportunities facing the world today and tomorrow, through unbiased, independent, and high-caliber research for the benefit of society. KAPSARC is located in Riyadh, Saudi Arabia.

\section{Legal Notice}

(C) Copyright 2018 King Abdullah Petroleum Studies and Research Center (KAPSARC). No portion of this document may be reproduced or utilized without the proper attribution to KAPSARC. 


\section{Key Points}

hina's political leadership has taken an increasingly public and proactive stance on climate change since 2014. This includes a commitment that Chinese carbon dioxide $\left(\mathrm{CO}_{2}\right)$ emissions will peak before 2030 and enacting measures through the 13th Five-Year Plan to support energy efficiency, clean energy technology, and carbon management. Chinese policymakers consider carbon capture and storage (CCS) a critical bridging technology to help accelerate the decarbonization of its economy. This paper reviews and analyses Chinese CCS support policies from the perspective of an adaptive policymaking framework, recognizing uncertainty as an inherent element of the policymaking process, and draws more general lessons for responding to changing circumstances.

Key insights from the analysis include:

Chinese CCS research, development, demonstration and deployment programs have matured to the point where the next step is to build and operate industrial-scale integrated CCS demonstration plants in specific sectors.

Capturing $\mathrm{CO}_{2}$ from industrial applications and utilizing the $\mathrm{CO}_{2}$ for enhanced oil recovery may be a technically feasible and economically attractive option for early demonstration and sector-specific deployment in China.

There are a variety of policy incentives that the Chinese government could consider to support early deployment of CCS. In terms of political economy, a clear case exists for using capital grants to not only support the demonstration phase but also to support sector-specific deployment of CCS.

In the long term, meeting the goals of China's national carbon policy regime will require CCS to become a cost-competitive mature emissions mitigation technology. The most efficient policies would make governmental support contingent on CCS technology performance passing through ex-ante defined policy gateways. These performance gateways provide a high level of policy predictability and consistency that is essential to securing commercial investment.

Performance gateways that do not presuppose how they will be met provide the flexibility needed to adapt policy to unpredictable developments, such as technological breakthroughs or process innovation that may affect the cost and performance characteristics of CCS.

The case study of CCS development in China can help other economies with a high degree of government involvement, including Saudi Arabia, to explore how an adaptive policy framework could be applied to support CCS development. 


\section{Summary for Policymakers}

C arbon capture and storage (CCS) is a potential bridge to a zero-carbon future for fossil fuel-dominated economies like China. Scenarios show that China will not achieve longterm carbon dioxide $\left(\mathrm{CO}_{2}\right)$ emissions reduction without CCS. For CCS to mature and be deployed at scale requires a series of policy instruments combining technology push and market pull. This paper analyzes the status of CCS development in China and proposes an 'adaptive' policy framework tailored to the Chinese situation. It allows for policy learning in response to the uncertainties and opportunities inherent in the technology maturation process; a feature that static technology roadmaps do not provide.

CCS in China has made significant progress as a result of substantial research and development funding over the last decade. Key achievements in this period include developing and piloting all main $\mathrm{CO}_{2}$ capture technologies (pre-combustion, postcombustion, and oxy-combustion), assessing $\mathrm{CO}_{2}$ storage potential in the Chinese subsurface, and demonstrating the country's first fully-integrated CCS project. China is now ready to start industrialscale, sector-specific demonstration with the aim of having the technology available around 2030 . Storage-focused $\mathrm{CO}_{2}$-enhanced oil recovery $\left(\mathrm{CO}_{2}\right.$-EOR) can make an important contribution to achieving this objective.

This paper sheds light on the policy instruments needed to achieve short- and long-term CCS development in China. It argues that China has an opportunity to promote domestic CCS projects through leveraging its proven capability to mobilize capital grants for major infrastructure investments. Alternative policy options, such as portfolio standard programs or tax incentives, require consensus building and coordination among various ministries, which are time-consuming and may not be appropriate for this phase of CCS demonstration.

Economy-wide carbon pricing measures could also be implemented to complement and reinforce more specific sectoral incentives for the deployment of CCS. Such measures should be driven by marketbased instruments that provide incentives for $\mathrm{CO}_{2}$ reduction, irrespective of the technology employed. Possible options include incorporating CCS in the planned national emission trading schemes, or a carbon tax on atmospheric $\mathrm{CO}_{2}$ emissions. This paper frames the discussion within an adaptive policymaking framework. It uses the notion of 'policy gateways' to ensure that CCS policymaking incorporates feedback from implementation experience, specifying policy gateways that are relevant for the Chinese CCS context.

China's experiences of CCS development also provide a useful context for exploring how an adaptive policy framework could be applied to support CCS and other clean energy technology development. There are some similarities to Saudi Arabia in terms of the extent of the government's role in the economy, which might lead to similar capabilities in mobilizing public resources for industry development. 


\section{China's Environmental and Climate Policy Context}

C hina is taking an increasingly proactive stance on climate change issues. As part of the 2015 Paris Accord, the country has committed to reducing the carbon intensity of its economy by $60-65$ percent by 2030 compared to 2005 levels, and to peak its carbon dioxide $\left(\mathrm{CO}_{2}\right)$ emissions no later than 2030. This is an ambitious task given China's high dependence on fossil energy, mainly coal, to fuel an economy still growing at around 6 percent annually (China National Statics Bureau 2017).

China's decarbonization effort relies heavily on deploying large-scale renewable and nuclear energy supported by efficiency improvements. It is also developing and demonstrating carbon capture and storage (CCS) technologies to decarbonize its fossil-based energy systems and is currently among the global leaders in this area. China is now on its way to launch its first integrated large-scale CCS demonstration project by 2020 along with implementing several advanced CCS research and development (R\&D) programs. This paper reviews and analyzes the status of CCS development from a policy perspective and outlines a course of further policy actions. Unlike a technology roadmap (e.g., ADB 2015), which focusses mainly on cost-efficient deployment scenarios, this paper takes an adaptive policy perspective. It acknowledges the political, economic, technological and institutional context for CCS in China, the inherent uncertainty associated with the development of large-scale, complex technologies such as CCS, and the need to balance the interests of various actors when formulating and implementing policy.

Coal has been the dominant fuel in China's power sector, accounting for 73 percent of the country's power generation in 2015 and 66 percent in
2016 (IEA 2016). Continued resource-intensive industrial development has turned China into the world's largest $\mathrm{CO}_{2}$ emitter, a position it has held since 2007. The problem is compounded by the deteriorating air quality of many of China's major cities and severe water contamination across the nation (Council on Foreign Relations 2017). China's political leadership has realized that the country cannot continue to operate its economy at the expense of the environment and has enacted several measures to address these environmental issues. These include implementing the first-ever amendments to its Environmental Protection Law (enacted in 1989) in January 2017. Alongside tougher environmental regulations, China also listed environmental governance as one of its top four priorities in the 13th Five Year Plan (State Council 2016).

China's climate policy exhibits a similarly marked change in attitude. At the 2009 United Nations Climate Change Conference (COP15), China announced two key emission reduction targets for 2020: reducing $\mathrm{CO}_{2}$ per unit of gross domestic product (GDP) by 40-45 percent compared to 2005 levels and increasing the share of non-fossil energy to 15 percent of primary energy consumption (UNFCCC 2010). In 2011, China included several additional energy and environmental targets within its 12th Five-Year Development Plan. In November 2014, the United States (U.S.)-China Joint Announcement on Climate Change stated that China intends to peak its $\mathrm{CO}_{2}$ emissions no later than 2030, and increase the non-fossil fuels share of its total primary energy consumption to 20 percent by 2030 (White House 2014).

In the following year, China reaffirmed its intention to reduce $\mathrm{CO}_{2}$ emissions per unit of GDP by $60-65$ 
percent from 2015 levels and to increase the forest stock volume by 4.5 billion cubic meters from 2005 levels by 2030 (White House 2015). In the same document, China committed to initiate national economy-wide emissions trading in 2017, and to demonstrate its first one-million-tonne integrated CCS project in Shanxi province by 2020 . China has incorporated many of its announced climate targets into its 13th Five-Year Plan (2016-2020), the country's most important economic planning document. Table 1 summarizes its current targets.
China's central government and state-owned energy companies have been aggressively pursuing the development of CCS since 2006, motivated by the realization that coal is likely to continue to play an important role in its primary energy mix over the next 30-50 years. Accordingly, cost-effective CCS that can be employed on a large scale in the power sector and various industrial sectors including steel, cement and refineries will enable China to meet its decarbonization goals (Bert et al. 2005; ADB 2015).

Table 1. Climate change-related targets in current and recent five-year economic development plans.

Targets 12th FYP 2011-2015 13th FYP 2016-2020

\begin{tabular}{l|l|l} 
Energy consumption per unit of GDP & $16 \%$ reduction (18.2\% achieved) & $15 \%$ reduction \\
\hline $\mathrm{CO}_{2}$ emissions per unit of GDP & $17 \%$ reduction $(20 \%$ achieved $)$ & $18 \%$ reduction \\
\hline $\begin{array}{l}\text { Non-fossil fuels consumption of } \\
\text { primary energy consumption }\end{array}$ & $\begin{array}{l}11.4 \% \text { at the end of } 12 \text { th FYP }(12 \% \\
\text { achieved })\end{array}$ & $15 \%$ at the end of 12 th FYP \\
\hline Total energy consumption cap & & 5 billion tonnes of coal equivalent \\
\hline Carbon intensity & & $40 \%-45 \%$ reduction $2020-2005$
\end{tabular}

Source: KAPSARC. 


\section{CCS Path to Market}

CS is a technically feasible but highly capital-intensive climate mitigation technology. Supporting the maturation of emerging low-carbon energy technologies into cost-effective $\mathrm{CO}_{2}$ mitigation technologies often requires policy intervention. A particular challenge along the path to maturity is the so-called 'valleys of death': points during the development and commercialization phases where funding (public and private) is increasingly stretched, unavailable, or simply insufficient. The 'valley of death' is just one of several challenges in developing an emerging technology. The existing environmental economics literature contains discussions of various types of market failures and public policy proposals to correct them. Grubb (2014), IEA (2012) and Krahé (2013) analyze these issues specifically in a CCS context. The crucial points contained in this literature are that:

Innovative emerging clean technologies will not make it to deployment without appropriate policy incentives.
The nature, scale and scope of policy incentives need to be calibrated to the specific needs of particular technologies. Policy incentives also need to change as technologies develop.

CCS is particularly prone to 'valley of death' issues, reflecting the magnitude of the upfront capital investment required to scale-up CCS, and the large implementation risks associated with deploying CCS technologies. Under the existing climate policy regime, the only attractive business case for $\mathrm{CCS}$ project developers is to use the captured $\mathrm{CO}_{2}$ for enhanced oil recovery (EOR). These obstacles highlight the development and commercialization challenges of CCS compared to other emerging low carbon energy technologies. Policy incentives will need careful calibration to address these issues if they are to be successful.

Figure 1 shows, the literature on innovation (e.g., Grubler et al. 2012) suggests that the path to market
Linear model of innovation process
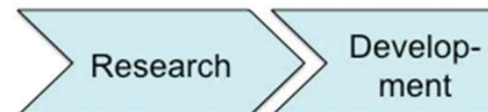
ment

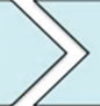
Demon-
stration $\gg$ Diffusion

Systematic representation of innovation with chainlinked model of innovation process

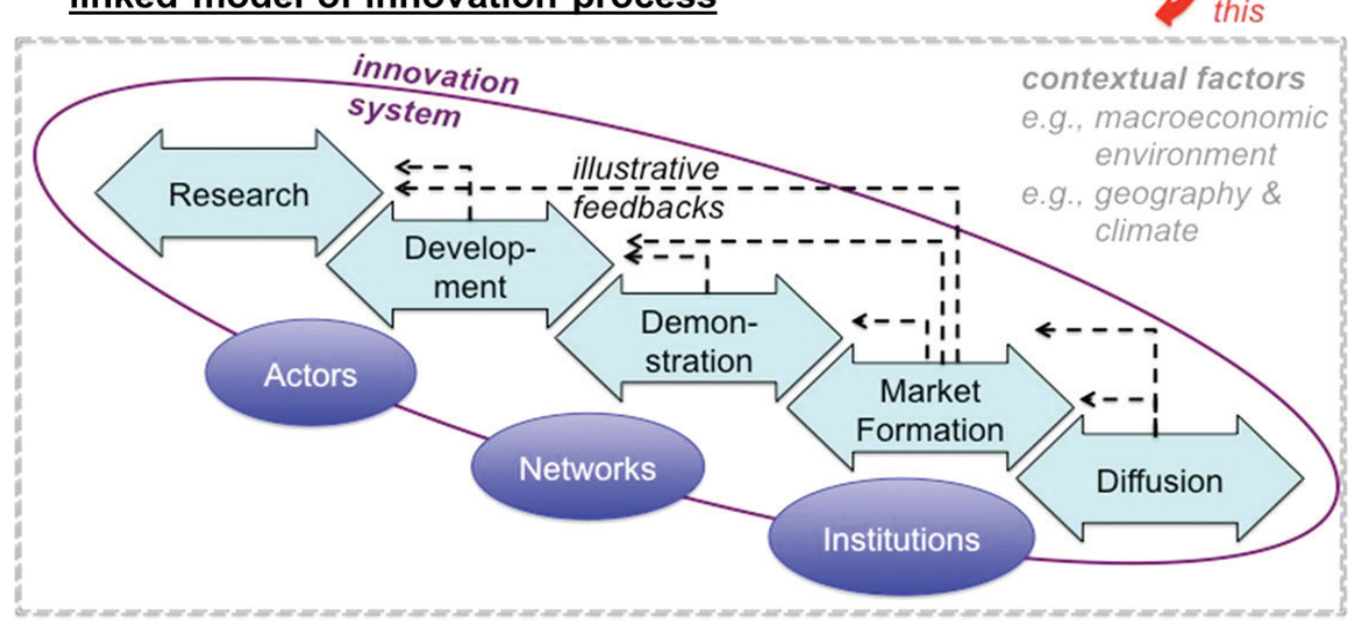

\section{Understanding} innovation:

\section{from}
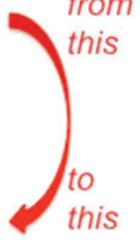

Figure 1. Energy technology innovation process (adopted from Grubler et al. 2012). 
for CCS comprises several development phases which link and partly overlap. The demonstration phase establishes the technical viability of CCS for practical deployment (IEA 2012). In the market formation phase, the technology is exposed to limited market-based learning that, in turn, reduces risk and cost and enhances investor confidence in the technology. This form of early market experience could come from sectorspecific deployment in niche markets that have the lowest cost for CCS initiatives, such as $\mathrm{CO}_{2}$-EOR.
Diffusion, the final stage of the deployment path, involves the wide-scale deployment of CCS driven by economies of scale, infrastructure and regulatory developments that together enable CCS to compete as a mature technology with other options to reduce $\mathrm{CO}_{2}$ emissions. As will be discussed in the next section, CCS in China is about to complete its demonstration phase and is now facing the challenges of sector-specific demonstration and deployment. The analysis conducted in this study focuses on these technology development phases. 


\section{Status of CCS in China}

hinese government funding has proven very effective in 'pushing' CCS along its initial development path. The country has supported early CCS through a variety of science and technology programs, summarized in Appendix 1. Research subsidies, estimated at about 3 billion yuan (CNY) (ADB, 2015) have delivered progress in the following areas:

\section{Integrated demonstration projects}

Table 2 gives a full list of current demonstration projects. Projects outside the power generation sector are particularly noteworthy: the coal-toliquids facility with saline aquifer storage operated by Shenhua Energy Group, and the combined CCS and $\mathrm{CO}_{2}$-EOR project by Yanchang Petroleum in Shanxi Province. By 2020 the latter project is expected to become China's first integrated million tonne per year CCS facility.

\section{Capture-side research, development, demonstration projects}

$\mathrm{CO}_{2}$ capture projects without geological storage include the Huaneng's 80,000 tonnes $\mathrm{CO}_{2}$ /year integrated gasification combined cycle-CCS project in Tianjin, the 120,000 tonnes $\mathrm{CO}_{2}$ /year postcombustion capture demonstration project at a super-critical coal-fired power plant in Shanghai, also operated by Huaneng, and the Huazhong University of Science and Technology's 35 megawatt

Table 2. Operational integrated CCS projects, China.

\begin{tabular}{|c|c|c|c|c|c|}
\hline $\begin{array}{l}\text { Integrated } \\
\text { projects }\end{array}$ & $\mathrm{CO}_{2}$ sources & Capture & Transport & $\begin{array}{l}\text { Utilization/ } \\
\text { storage }\end{array}$ & Operational year \\
\hline $\begin{array}{l}\text { CNPC-Jilin } \\
\mathrm{CO}_{2} \text {-EOR } \\
\text { demonstration }\end{array}$ & $\begin{array}{l}\text { Natural gas } \\
\text { processing }\end{array}$ & Pre & Pipeline ( 50km) & $\begin{array}{l}\text { EOR }(300,000 \\
\text { tonnes } \mathrm{CO}_{2} \text { per } \\
\text { year })\end{array}$ & 2007 \\
\hline $\begin{array}{l}\text { CNPC-Daqing Oil } \\
\text { Field } \mathrm{CO}_{2} \text {-EOR } \\
\text { demonstration }\end{array}$ & $\begin{array}{l}\text { Natural gas } \\
\text { processing }\end{array}$ & Pre & Truck \& Pipeline & $\begin{array}{l}\text { EOR }(200,000 \\
\text { tonnes } \mathrm{CO}_{2} \text { per } \\
\text { year })\end{array}$ & 2003 \\
\hline $\begin{array}{l}\text { Sinopec-Shengli } \\
\text { CCS Project }\end{array}$ & Power generation & Post & Trucks ( 80km) & $\begin{array}{l}\text { EOR }(40,000 \\
\text { tonnes } \mathrm{CO}_{2} \text { per } \\
\text { year })\end{array}$ & 2010 \\
\hline $\begin{array}{l}\text { Shenhua Ordos } \\
\text { CCS project }\end{array}$ & Coal-to-liquids & Pre & Truck ( 11km) & $\begin{array}{l}\text { Saline }(100,000 \\
\text { tonnes } \mathrm{CO}_{2} \text { per } \\
\text { year })\end{array}$ & $2011-2014$ \\
\hline $\begin{array}{l}\text { Sinopec- } \\
\text { Zhongyuan } \\
\mathrm{CO}_{2} \text {-EOR project }\end{array}$ & Chemical & Pre & Truck & $\begin{array}{l}\text { EOR }(120,000 \\
\text { tonnes } \mathrm{CO}_{2} \text { per } \\
\text { year) }\end{array}$ & 2015 \\
\hline Xinjiang Dunhua & Petrochemical & Post & Truck & $\begin{array}{l}\text { EOR }(100,000 \\
\text { tonnes } \mathrm{CO}_{2} \text { per } \\
\text { year) }\end{array}$ & 2015 \\
\hline
\end{tabular}

Source: KAPSARC. 
(MW) oxy-combustion demonstration project. A main function of these projects has been to discover the cost of $\mathrm{CO}_{2}$ capture in China (Table 3).

\section{Geological storage capacity estimation}

From 2001-2012 the Chinese Geological Survey assessed the potential for geological storage of $\mathrm{CO}_{2}$ in the Chinese subsurface, focusing on major basins (Figure 2). $\mathrm{CO}_{2}$ storage potential in China is estimated at around 1,900 gigatonnes $\mathrm{CO}_{2}$, combining saline aquifer storage and depleted oil and gas fields (ADB 2015; Liu et al. 2017).

\section{$\mathrm{CO}_{2}$ utilization research}

$\mathrm{CO}_{2}$ utilization technology has the potential to help offset the high cost of carbon capture, thereby providing a stepping stone for commercial CCS projects. The Ministry of Science and Technology (MOST) has been supporting $\mathrm{CO}_{2}$ utilization research. Research topics that received funding over the last 10 years include the use of $\mathrm{CO}_{2}$ to produce a biodegradable polymer, $\mathrm{CO}_{2}$-EOR,
$\mathrm{CO}_{2}$-enhanced shale gas recovery, and using $\mathrm{CO}_{2}$ to cultivate algae for biofuels or fertilizers. With support from MOST, a Chinese company in Jiangsu Province has been utilizing around 10,000 tonnes of $\mathrm{CO}_{2}$ a year since 2007 to produce polypropylene carbonate, which can be used for biodegradable plastics.

Despite substantial progress, there have also been challenges. Given the high up-front capital investment required by CCS demonstration projects and current low oil prices, some previously announced large-scale CCS demonstration projects have not materialized. The project planned by Sinopec, one of China's state-owned oil companies, to capture one million tonnes of $\mathrm{CO}_{2}$ from a power plant for $\mathrm{CO}_{2}$-EOR in the company's Shengli Oil Field, is a case in point. The power plant started operating in 2010, and from 2012 MOST supported the research component of this project through the National Key Science and Technology Project Program. With continued low oil prices, Sinopec postponed taking the final investment decision, arguing that the economics of the project did not meet the company's investment criteria. This example exemplifies the technology 'valley of

Table 3. Current $\mathrm{CO}_{2}$ capture cost in China (compiled by authors from various sources).

\begin{tabular}{|c|c|c|}
\hline Capture type & Cost & Scale \\
\hline Post-combustion - power sector & $\mathrm{CNY} 300 / \mathrm{tCO}_{2}\left(\right.$ around $\left.\$ 46 / \mathrm{tCO}_{2}\right)$ & 200 ktonne/year \\
\hline Pre-combustion - power sector & 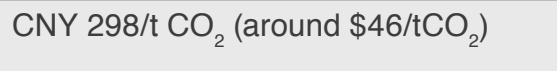 & 80-100 ktonne/year \\
\hline Oxy-demonstration - power sector & $\begin{array}{l}\text { CNY 500-600/tCO }{ }_{2} \text { (around } \$ 75 / \mathrm{tCO}_{2} \text { ) } \\
\text { for } 35 \mathrm{MW} \text { (first-of-kind power-plant); }\end{array}$ & $\begin{array}{l}100 \text { ktonne/year (based on the project } \\
\text { plan) }\end{array}$ \\
\hline Coal-to-chemical & CNY $200 / \mathrm{tCO}_{2}\left(\right.$ around $\$ 30 / \mathrm{tCO}_{2}$ ) & 460 ktonne/year \\
\hline
\end{tabular}

Source: KAPSARC. 


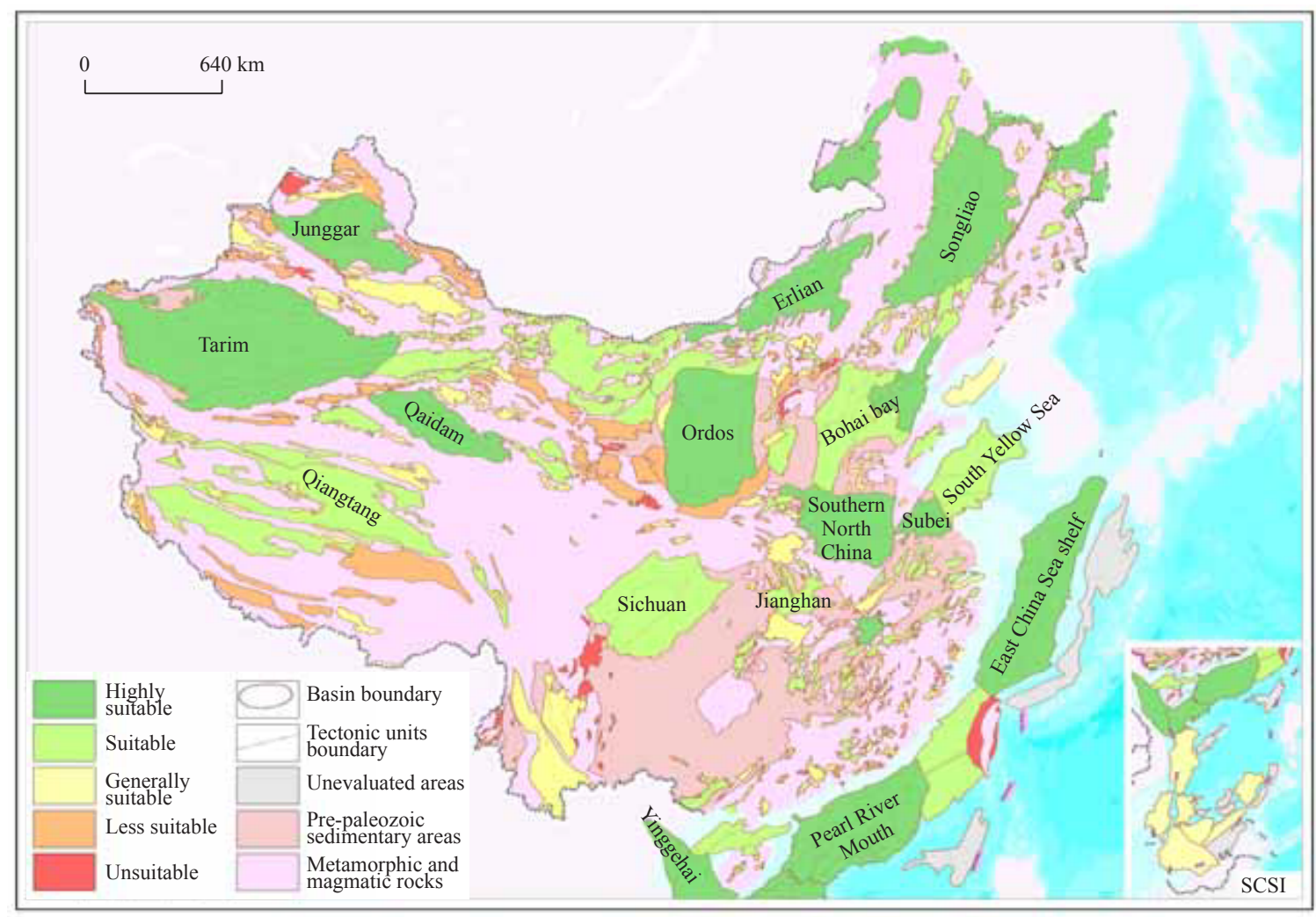

Figure 2. Storage suitability of major basins in China (adapted from Gao et al. 2015).

Source: KAPSARC.

death': the cost of further deployment is increasing and cannot be met without direct governmental subsidies, and private capital is insufficient to make up the difference.

\section{Moving to industrial-scale demonstration}

The next stage of CCS development is expected to focus on limited industrial-scale demonstration of CCS in specific sectors. A reasonable and viable deployment scenario for CCS in this phase could include:

\section{CCS in industrial applications}

Application of CCS in the industrial sector is attractive since it has limited options to reduce emissions without CCS. There are no alternative industrial processes to produce steel and cement and to refine chemicals.

This is different from the situation in the power sector where CCS is one of several low carbon energy technologies available to decarbonize electricity generation. Moreover, capture costs in the industrial sector tend to be lower than those in the power sector, since the industrial sector can capture $\mathrm{CO}_{2}$ from flue gases in a purer and more concentrated form. The application of CCS is particularly warranted in coal-to-chemicals processes, given the large amounts of highly-concentrated $\mathrm{CO}_{2}$ coal conversion produces.

\section{CCS as part of $\mathrm{CO}_{2}$-EOR}

$\mathrm{CO}_{2}$-EOR operations could provide a particularly cost-effective form of storage. The costs associated with finding and exploring the storage formation can be significant for aquifer 
storage but are negligible for EOR projects, since the exploration work has already occurred in the primary oil recovery process. Moreover, the benefit of enhanced oil revenue from $\mathrm{CO}_{2}$ injection helps to offset the costs of $\mathrm{CO}_{2}$ storage.

The following figure helps to illustrate the potential opportunity of $\mathrm{CO}_{2}$-EOR for China. Assuming that $\mathrm{CO}_{2}$ is delivered free of charge, Ward (2017) estimates that about 750 million tonnes of $\mathrm{CO}_{2}$ from existing $\mathrm{CO}_{2}$ sources could be stored through $\mathrm{CO}_{2}$-EOR projects that have a zero or positive net present value (NPV). If the constraint regarding availability from currently operating $\mathrm{CO}_{2}$ sources is relaxed, $\mathrm{CO}_{2}$-EOR projects with a zero or positive NPV could store about 11 billion tonnes of $\mathrm{CO}_{2}$. Most of this potential storage comes from Shengli and Daqing oil fields.

\section{Establishing a $\mathrm{CO}_{2}$ transportation network}

A transportation network that can be accessed by multiple CCS operators is essential for realizing the full scope of emission reductions from CCS. In China, most $\mathrm{CO}_{2}$ deliveries for utilization or storage is by truck: an expensive and unsuitable way to transport large volumes of $\mathrm{CO}_{2}$. As CCS development takes place against a backdrop of uncertainty regarding future infrastructure demand, there is a substantial need for coordination project operators for capture, transport, and utilization and storage, a task that public policy is best placed to address.

Table 4. Total economic storage (project $\mathrm{NPV} \geq 0$ ) when $\mathrm{CO}_{2}$ is delivered free of charge. Storage numbers are both for present-day $\mathrm{CO}_{2}$ and for a reference situation of unlimited $\mathrm{CO}_{2}$ supply (Ward 2017).

$\mathrm{CO}_{2}$ supply constrained by availability (million tonnes $\mathrm{CO}_{2}$ )
Unlimited $\mathrm{CO}_{2}$ supply (million tonnes $\mathrm{CO}_{2}$ )

\begin{tabular}{l|l|l}
\hline Pre-tax & 1900 & 12070 \\
\hline Post-tax & 751 & 10919
\end{tabular}

Source: KAPSARC. 


\section{Policy Drivers and Potential Instruments}

T The government has a number of policy instruments to choose from to support CCS development and deployment. IEA (2012) gives an overview of the main instruments. The paper suggests that capital grants, i.e., competitive or administrative direct government capital contributions toward CCS construction, are appropriate or even essential for the demonstration phase. However, sector-specific CCS deployment is unlikely to be feasible with public grants alone. A mix of policy instruments appropriate for this phase includes the following:

Capital or production subsidies: investment and production tax credits that reduce the tax liability for a firm that operates CCS assets, including capture, transport, and storage.

Performance standards: a portfolio obligation requiring CCS-fitted fossil-based plants to produce a certain percentage of output.

Infrastructure support: government acting either directly or through agents to provide infrastructure planning for system development. Due to long lead times -6 to 10 years to build facilities such as pipelines (ZEP 2013) $-\mathrm{CO}_{2}$ transportation and storage infrastructure development must start early.

There is broad evidence that competing, and at times conflicting, policy priorities, political aspirations, public acceptance levels, local economic and industrial conditions, and institutional structure play determining roles in eventual policy implementation. A range of policy considerations including economic, fiscal, industrial, regional development, and environmental factors will impact public support for CCS. Environmental, industrial, and regional development factors are likely to outweigh the economic and fiscal dimensions in China. As such, China supported its policy objective to become a leader in the renewable energy industry with a raft of policy instruments, including capacity targets, subsidies, standardizing renewable energy products, tax rebates for equipment manufacture, and customs duties for equipment export (see Appendix 2). Issues of cost-effectiveness and the appropriate allocation of risk and reward do not appear to have been major factors in the choice of policy instruments supporting renewables (Zhao et al. 2014).

\section{Demonstration and sector- specific deployment}

It is unclear whether the Chinese Government's policy support for CCS will be as comprehensive and generous as its support for renewable energy. What is clear, however, is that capital grants are likely to be the preferred means of supporting CCS in China during the demonstration phase and in driving sector-specific deployment. This is at variance with the accepted economic view that grant funding should be restricted to the demonstration phase, to avoid overstretching the government's fiscal resources. However, the Chinese government has traditionally been good at using capital grants or direct support to deliver large-scale industrial projects, like the Three Gorges Dam, early high-speed train development, and early nuclear power projects. In fact, there is a growing voice from the CCS community advocating the government to include ongoing CCS deployment in China's National Major Construction Projects Program, most of which is entirely financed by the central government. 
In contrast to grant funding, government support via portfolio standards or tax policy appears more difficult since it requires the involvement of a variety of government ministries and agreement at the State Council level. Given the present lack of coordination on issues related to CCS among the involved ministries and their competing policy priorities, the practical barrier to securing broad agreement for such policies appears to be very high.

However, this assessment may not apply to storagefocused $\mathrm{CO}_{2}$-EOR projects. First, $\mathrm{CO}_{2}$-EOR projects are subject to China's well-established petroleum production regime, which focuses on optimizing oil production to maximize associated taxation and resource rent revenues. The oil production regime is managed through a number of provisions, which include inter alia the requirement of production sharing, the imposition of a resources tax set at 6 percent of the crude selling price, and a 25 percent tax on corporate earnings (U.S. EIA 2016). Second, since 2014, oil produced via $\mathrm{CO}_{2}$ flooding can benefit from a 30 percent resource tax exemption. Adjusting the fiscal regime to give more favorable treatment to $\mathrm{CO}_{2}$-EOR projects is an appropriate support measure, given the huge potential for $\mathrm{CO}_{2}$ storage.

Given the costs and risks involved, transportation infrastructure is most likely to develop incrementally from point-to-point links between individual emitters and storage sites, and without the scale required to support the timely and efficient development of local or regional clusters. Such a development path could pose a substantial practical barrier to efficient and timely CCS development in China. Cluster-scale infrastructure development will require strategic coordination and the pooling of cluster investments and financing. The government is best placed to provide this strategic leadership, and to support the development of the key transportation infrastructure, by underwriting a proportion of the network costs. There is also a role for government regulation to ensure access to the network for individual CCS operators on fair and reasonable terms and to guarantee the fair recovery of network costs. Given the long lead times for infrastructure development, early government involvement is essential for the timely development and cost-effective deployment of CCS.

\section{Commercial deployment}

In the longer term, China could include CCS in its national carbon policy regime. In principle, economy-wide carbon pricing would allocate the emission reduction burden efficiently across the economy, ensuring $\mathrm{CO}_{2}$ is mitigated at least cost. The Chinese government launched the first phase of a national emissions trading program in December 2017. The country has already gained experience in emissions trading through seven pilot projects that operated between 2013 and 2015. The first phase of the national emissions trading program only regulates the power sector. The first round of the emissions trading program does not include CCS. However, establishing an emissions trading system sends a signal to the business community to incorporate carbon constraints in their operational and investment decisions. In this way, a carbon price can potentially complement and reinforce sectoral policies designed to promote CCS. The government is currently working with experts on the specifics of incorporating CCS into the emissions trading scheme. Their priority is to resolve the permit allowance allocation method, and the monitoring, reporting and verification requirements.

Senior officials from the National Development and Reform Commission (NDRC) and Ministry of Finance have also discussed the possibility of implementing a nationwide carbon tax after 2020, to 
support the diffusion and deployment of low-carbon energy technologies. Despite the current U.S. administration's critical view of climate change and the Paris accord, China has repeatedly stated its intention to proceed with its planned climate efforts, providing the predictability and consistency needed to underpin its emissions reduction policy.

\section{Policy implementation}

The discussion so far has focused on identifying a complementary set of policy instruments that could support the development of CCS into a mature technology. These instruments include capital grants supporting large-scale CCS demonstration and construction, a favorable fiscal regime for $\mathrm{CO}_{2}$-EOR, and government action to develop $\mathrm{CO}_{2}$ transportation infrastructure. China's emissions trading program could provide more general support as it expands to include the entire economy from 2030. The resulting economy-wide carbon price could potentially provide further support for CCS on a technology-neutral basis.

To be most effective, these instruments need to be deployed in an integrated way that reflects the objectives of an overarching policy framework. The policy framework needs to reflect the inherent uncertainties associated with the development and deployment of new low carbon energy technologies like CCS. The uncertain nature and rate of innovation in low carbon energy technologies mean that technological progress is unlikely to be linear. Policy frameworks need to be able to respond to such uncertainty quickly and effectively lest they themselves become a barrier to desirable technological progress, or unduly distort technological development and deployment.

Experience suggests the most effective policy frameworks are holistic, objective and adaptable.
They are holistic in that they consider technological development in its entirety and seek to provide an interrelated set of targeted stimuli that complement and reinforce incentives for efficient, innovative and timely development and deployment. Holistic policy frameworks help to avoid unintended consequences that can potentially derail or fundamentally distort such timely and effective technological development and deployment.

Effective policy frameworks also seek to establish clear, outcomes-based policy objectives. They are not bound by timetables or timelines, recognizing that technological development is inherently uncertain and rarely proceeds according to a predetermined administrative program. And they do not prescribe how to achieve a policy goal. Instead, they seek to create and reinforce incentives to encourage participants to work out the most timely and innovative way to meet the objective, using whatever cost-effective combination of technologies and commercial arrangements are available.

Most importantly, effective policy frameworks are adaptable. They can change the range and combination of policies, or moderate policy priorities quickly and effectively. This ensures that the policy framework remains relevant and effective in response to changing technological developments, commercial innovation, relative costs, unanticipated developments and evolving policy priorities. In practice, regular policy evaluation and review based on operational evidence and other information gathered from the incremental implementation of support programs, among other things, can build adaptability into the policy process. Three- to fiveyear timeframes are probably appropriate in this context. They would be sufficient to test and assess policy interventions while enabling timely responses to changing circumstances that avoid potentially harmful 'policy lock-ins.' A five-year timeframe would 
also be consistent with the review period proposed under the Paris Agreement (Falkner 2016).

A holistic, objective and adaptable policy framework should be designed so as "not to be optimal for a best estimate future, but [should seek to be] robust across a range of plausible futures" (Walker et al. 2001). Existing literature suggests various tools to endow policy frameworks with the adaptability needed to support effective implementation (Swanson et al. 2010). IEA (2012) espouses a particularly relevant approach to CCS, relying on 'gateways' or 'milestones' that link governmental policy to the achievement of certain technology performance thresholds. The policy gateways include three key components:

Type of policies used in each stage of the CCS development cycle.
Criteria for determining changes in support policy.

Contingency plans outlining how the government would respond if gateways are missed.

The government offers a medium-term commitment to specific policies through the gateway process.

This commitment provides the private sector with a high degree of consistency and predictability within the objective-based goals and bounds established by the overarching CCS policy framework.

Figure 3 specifies possible 'gateways' pertaining to the demonstration and sector-specific deployment phases.

Comparing the actual state of CCS in China with the metric presented in the table suggests that CCS policy has completed most of the demonstration
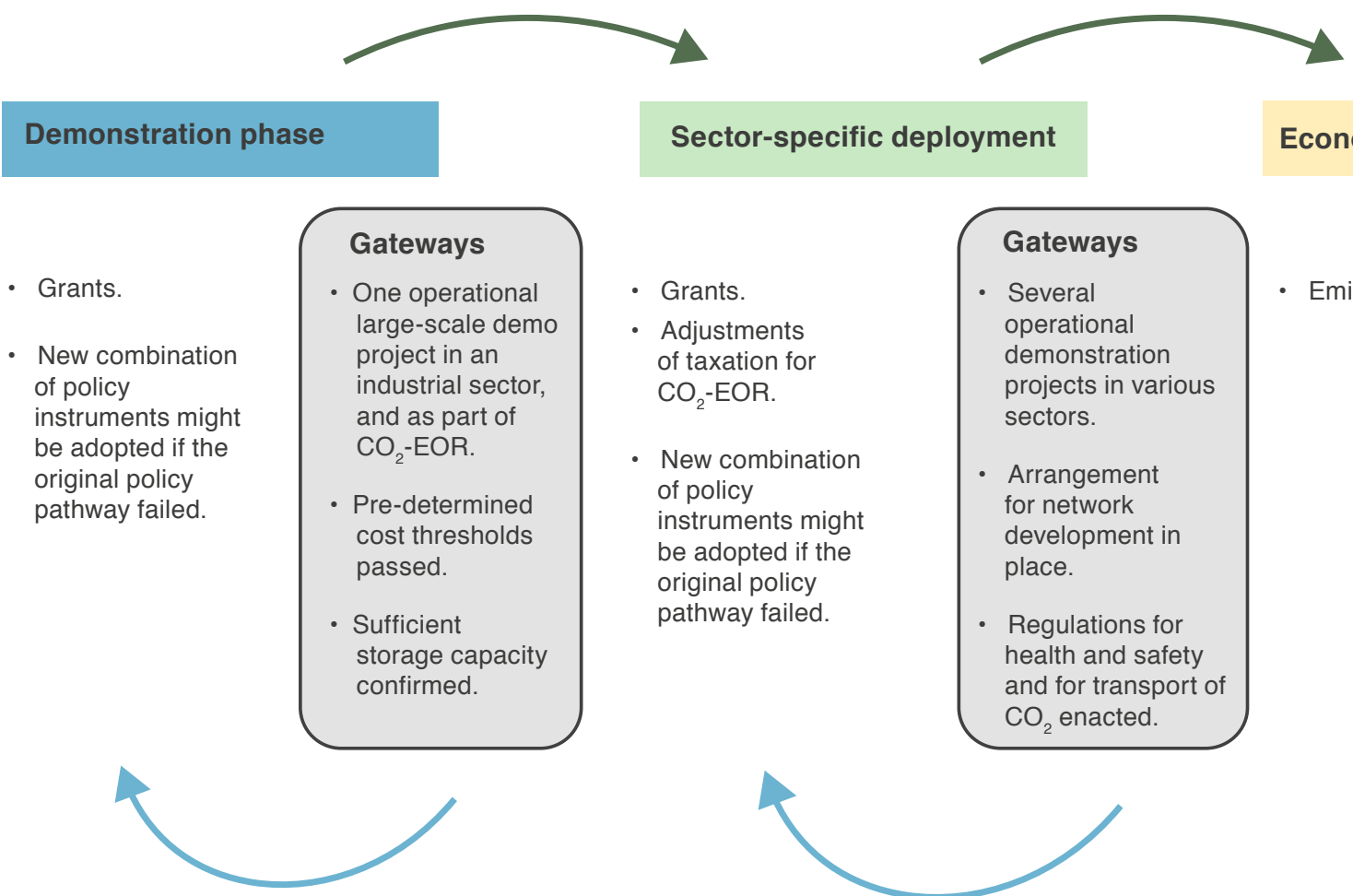

- Grants.

- Adjustments of taxation for $\mathrm{CO}_{2}$-EOR.

- New combination of policy instruments might be adopted if the original policy pathway failed.

\begin{tabular}{l}
\hline Gateways \\
Several \\
operational \\
demonstration \\
projects in various \\
sectors. \\
- Arrangement \\
for network \\
development in \\
place. \\
Regulations for \\
health and safety \\
and for transport of \\
$\mathrm{CO}_{2}$ enacted.
\end{tabular}

- Emissions trading.

Figure 3. Potential CCS policy gateways in China.

Source: KAPSARC. 
phase milestones and should prepare to tackle sector-specific demonstration.

Formulating the policy response for when 'gateway' milestones have not been fully achieved could be difficult in practice. The response will greatly depend on the nature of the failure and circumstances surrounding it. For example, there may be a range of potentially credible responses to a case where there are not enough projects operating to justify including CCS in the emissions trading scheme. These include extending the capital grant-funding program, targeted R\&D funding to address observed technological barriers, or potentially mandating CCS construction. Alternatively, the government may continue to introduce a moderate economy-wide carbon pricing scheme, accepting that it may not lead to CCS deployment.

Whatever path is taken, the government needs to take care to avoid responses that are inconsistent with a holistic, objective and adaptive policy approach. Incremental change demonstrably based on objective evidence is desirable, rather than radical amendments likely to undermine confidence in the overall policy framework and the government's commitment to implementing it. Policy responses need to be credible, and need to be perceived to be credible by key stakeholders, if they are to have the desired effect. 


\section{Conclusion}

his paper discusses the key features of an adaptive policy framework that could support and drive the development of CCS. After a decade's effort on CCS R\&D, China is ready to move the technology to the demonstration phase or early sector-specific deployment. Capturing $\mathrm{CO}_{2}$ from industrial applications and utilizing the $\mathrm{CO}_{2}$ for EOR may provide China with an early opportunity to achieve an integrated industrial-scale CCS demonstration: a path to early commercial deployment. The Chinese government could consider a variety of policy incentives to support CCS development in the short term. Based on China's past experiences, using capital grants to support the demonstration and sector-specific deployment of CCS might be most effective and efficient. In the long term, CCS will need to be integrated into China's national carbon policy regime so it can evolve to be more cost-competitive. In China today, governmental support for CCS is still fragmented, with uncoordinated government leadership, undecided industry players, and competing voices from some leading scientists. Given the beneficial role CCS could play in decarbonizing China's power sector, and other industrial sectors, commitment to CCS from senior policymakers and major stakeholders is needed. CCS will be delivered most effectively through a holistic, objective and adaptable policy framework.

An adaptive policy framework consisting of several policy gateways has the potential to allow the government to apply a more flexible and incremental policy approach. This approach is better suited to the inherent unpredictability that may affect the development of emerging low-emission technologies like CCS. It also provides a way of delivering the level of policy predictability and consistency essential for private investment.

\section{Policy implications for the Kingdom of Saudi Arabia}

CCS development in China provides a useful case study to explore how an adaptive policy framework could potentially support CCS development in the Kingdom of Saudi Arabia. Given the Kingdom has a similar centrally planned economic governance structure to China, China's experience of implementing policies to drive the development of clean energy sectors might provide valuable lessons and guidance for Saudi Arabia's policymakers. 


\section{References}

Asian Development Bank (ADB). 2015. "Roadmap for Carbon Capture and Storage Demonstration and Deployment in the People's Republic of China." Accessed July 24, 2017. https://www.adb.org/sites/default/files/ publication/175347/roadmap-ccs-prc.pdf

China National Bureau of Statics. 2017. "The Second Quarter and the first half of 2017 of China's GDP preliminary accounting results." Accessed July 24, 2017. http://www.stats.gov.cn/tjsj/sjjd/201707/ t20170717 1513669.html

Council on Foreign Relations. "China's Environmental Crisis." Accessed July 25, 2017. https://www.cfr.org/ blog-post/chinas-june-reserves

Falkner, Robert. 2016. "The Paris Agreement and the new logic of international climate politics." International Affairs 92, no. 5: 1107-1125. DOI: https://doi. org/10.1111/1468-2346.12708

Grubb, Michael. 2014. Planetary Economics - Energy, Climate Change and the Three Domains of Sustainable Development. London: Routledge.

Huiru, Zhao, Sen Guo, Liwen Fu. 2014. "Review on the cost and benefits of renewable energy power subsidy in China." Renewable and Sustainable Energy Reviews 37: 538-549. DOl: https://doi.org/10.1016/j.rser.2014.05.061

International Energy Agency (IEA). 2012. "A policy strategy for carbon capture and storage." International Energy Agency. Information Paper.

International Energy Agency (IEA). 2016. The potential for equipping China's existing coal fleet with carbon capture and storage. Paris: OECD/IEA.

Grubler, Arnulf, Francisco Aguayo, Kelly Gallagher, Marko Hekkert, Kejun Jiang, Lynn Mytelka, Lena Neij et al. 2012. "Policies for the Energy Technology Innovation System." In Global Energy Assessment, edited by Thomas B Johansson, Anand Prabhakar Patwardhan, Nebojša Nakićenović, and Luis Gomez-Echeverri. Cambridge: Cambridge University Press.
Metz, Bert, Ogunlade Davidson, Heleen de Coninck, Manuela Loos, and L. A. Meyer. 2005. "IPCC special report on carbon dioxide capture and storage." Prepared by Working Group III of the Intergovernmental Panel on Climate Change." Cambridge: Cambridge University Press.

Jianqiang, Guo, Dongguang Wen, Senqi Zhang, Tianfu $\mathrm{Xu}$, Xufeng Li, Yujie Diao, and Xiaofeng Jia. 2015. "Potential and suitability evaluation of $\mathrm{CO}_{2}$ geological storage in major sedimentary basins of China, and the demonstration project in Ordos Basin." Acta Geologica Sinica (English Edition) 89, no. 4: 1319-1332. DOI: https://doi.org/10.1111/1755-6724.12531

Krahé, Max, Wolf Heidug, John Ward and Robin Smale. 2013. "From demonstration to deployment: An economic analysis of support policies for carbon capture and storage." Energy Policy 60:753-763. DOI: https://doi. org/10.1016/j.enpol.2013.05.019

Swanson, Darren, Stephan Barg, Stephen Tyler, Henry Venema, Sanjay Tomar, Suruchi Bhadwal, Sreeja Nair, Dimple Roy and John Drexhage. 2010. "Seven tools for creating adaptive policies." Technological Forecasting and Social Change 77:924-938. DOI: https://doi. org/10.1016/j.techfore.2010.04.005

U.S. Energy Information Administration EIA. 2016. China. Accessed 18 November 2018. https:// www.energy.gov/sites/prod/files/2016/04/f30/ China International Analysis US.pdf

UNFCCC. 2010. Communication of the Department of Climate Change, National Development and Reform Commission of China to the UNFCCC Secretariat, 28 January 2010. Accessed 18 June 2017. http://unfccc.int/ files/meetings/cop 15/copenhagen accord/application/ pdf/chinacphaccord app2.pdf

Walker, Warren E., S. Adnan Rahman and Jonathan Cave. 2001. "Adaptive policies, policy analysis, and policy-making." European Journal of Operational Research 128:282-289. DOI: https://doi.org/10.1016/ $\underline{\mathrm{S} 0377-2217(00) 00071-0}$ 
Ward, Colin, Wolfgang Heidug and Nils-Henrik Bjurstrom. 2017. "Enhanced oil recovery and global $\mathrm{CO}_{2}$ storage potential: an economic assessment." KAPSARC, KS-2018-DP27. Accessed 18 Feb 2018. https://www. kapsarc.org/wp-content/uploads/2018/04/KS-2018WB015-Decarbonizing-Oil-The-Role-of-CO2-EnhancedOil-Recovery.pdf DOI: https://doi.org/10.30573/ KS-2018--DP27

White House. 2014. "U.S.-China Joint Announcement on Climate Change." Accessed 18 June 2017. https://obamawhitehouse. archives.gov/the-press-office/2014/11/11/ us-china-joint-announcement-climate-change
White House. 2015. "U.S.-China Joint Presidential Statement on Climate Change." September 25. Accessed 18 June 2017. https://obamawhitehouse. archives.gov/the-press-office/2015/09/25/ us-china-joint-presidential-statement-climate-change

Zero Emissions Platform (ZEP). 2013. "Building a $\mathrm{CO}_{2}$ Transport Infrastructure in Europe." Accessed 18 November 2017. http://www.zeroemissionsplatform.eu/ ccs-technology/transport.html 
Table 1A. Overview of policies to 'push' CCS.

\begin{tabular}{|c|c|c|c|}
\hline Year & Ministry & Policy & Main Contents \\
\hline 2006 & State Council & $\begin{array}{l}\text { National Medium- and Long-Term Program } \\
\text { for Science and Technology Development } \\
(2006-2020)\end{array}$ & $\begin{array}{l}\text { Develop highly efficient, clean, and zero } \\
\text { carbon fossil technologies. }\end{array}$ \\
\hline 2007 & State Council & $\begin{array}{l}\text { China's National Climate Change Program } \\
(2007-2010)\end{array}$ & Further develop CCUS technologies. \\
\hline 2007 & $\begin{array}{l}14 \text { ministries including } \\
\text { MOST }\end{array}$ & $\begin{array}{l}\text { China's Scientific and Technological } \\
\text { Actions on Climate Change (2007-2020) }\end{array}$ & Include CCS in the priority areas. \\
\hline 2011 & MOST & $\begin{array}{l}\text { The 12th Five-Year Plan on Science and } \\
\text { Technology }\end{array}$ & $\begin{array}{l}\text { Regard CCUS as one of the strategic low- } \\
\text { carbon technologies. }\end{array}$ \\
\hline 2011 & State Council & $\begin{array}{l}\text { The 12th Five-Year Plan on Greenhouse } \\
\text { Gas Reduction }\end{array}$ & $\begin{array}{l}\text { Demonstrate CCUS technologies in power } \\
\text { sector, steel industry, cement industry, as } \\
\text { well as coal-chemical industry. }\end{array}$ \\
\hline 2012 & $\begin{array}{l}16 \text { ministries led by } \\
\text { MOST }\end{array}$ & $\begin{array}{l}\text { The 12th Five-Year Plan on Climate } \\
\text { Change Science Program }\end{array}$ & $\begin{array}{l}\text { Focus on cost reductions and business } \\
\text { model of CCUS technologies; further } \\
\text { enhance international cooperation, } \\
\text { including capacity building, technology } \\
\text { standardization, etc. }\end{array}$ \\
\hline 2012 & 4 ministries & $\begin{array}{l}\text { Blueprint for Climate Action in Industrial } \\
\text { Sector }\end{array}$ & $\begin{array}{l}\text { Explore CCUS technologies under the } \\
\text { Chinese context. }\end{array}$ \\
\hline 2013 & NDRC & Promoting CCUS Industrial Demonstration & $\begin{array}{l}\text { Encourage industrial players to } \\
\text { demonstrate CCUS technologies. }\end{array}$ \\
\hline 2013 & State Council & $\begin{array}{l}\text { National Medium and Long Term Plan } \\
\text { on Major Scientific and Technological } \\
\text { Infrastructure }\end{array}$ & $\begin{array}{l}\text { Further study and develop CCUS } \\
\text { technologies for climate change. }\end{array}$ \\
\hline 2013 & $\begin{array}{l}\text { Ministry of Environmental } \\
\text { Protection }\end{array}$ & $\begin{array}{l}\text { Calling for Environmental Protection for } \\
\text { CCUS Demonstration Projects }\end{array}$ & Environmental guidelines. \\
\hline 2014 & NDRC & $\begin{array}{l}\text { National Climate Change Action Plan } \\
2014-2020\end{array}$ & $\begin{array}{l}\text { Implement integrated CCUS demonstration } \\
\text { projects; include CCUS as an important } \\
\text { low carbon technology. }\end{array}$ \\
\hline 2014 & MOST and MIIT & $\begin{array}{l}\text { Special Program for Energy Saving and } \\
\text { Emissions Reduction Technology }\end{array}$ & \\
\hline 2014 & NDRC & $\begin{array}{l}\text { Upgrading and Reforming of Energy } \\
\text { Saving and Emissions Reduction of Coal } \\
\text { Power Sector 2014-2020 }\end{array}$ & Further study of CCUS technologies. \\
\hline
\end{tabular}




\section{Lessons from renewable energy development in China}

The development of renewable energy in China has greatly benefited from various industry policy instruments. Installed wind power capacity, for example, was only 0.567 gigawatts (GW) in 2003 but reached $149 \mathrm{GW}$ in 2016 . The following steps were taken to support this scale-up:

2009 NDRC introduced a feed-in tariff for onshore and offshore wind.

2010 Ministry of Finance removed import duty on wind and hydro technological equipment.

2012 Ministry of Science and Technology issued a wind power technology development program.

2013 12th Five Year Special Planning.

NDRC issued a notice on the improvement of the grid connection and feed-in of wind electric power generation.

NDRC announced feed-in-tariffs for offshore wind power.

2016 NDRC published the 13th Wind Energy Development Five-Year Plan.

NDRC and National Energy Administration issued plans for a renewable energy quota system to help accelerate the country's transition to a low carbon economy. Under the planned quota system, each of China's provinces will be responsible for ensuring that a certain percentage of their electricity consumption will come from non-hydro renewable energy sources, primarily wind, solar and biomass.

2017 Chinese government announced spending of more than $\$ 360$ billion through 2020 on renewable power sources, such as solar and wind.

The policy instruments enacted to support renewables range from strategic planning to specific policy instruments, including grants, subsidies, feed-in tariffs, and research, development and demonstration support. A powerful advocacy coalition is behind more than a decade's consistent policy push. It includes senior political leadership, policymakers at the ministry level, state-owned enterprises, industry associations, and prominent research institutes. 


\section{About the Authors}

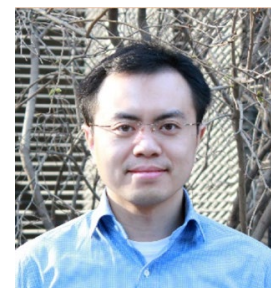

\section{Xiaoliang Yang}

Xiaoliang is a visiting researcher at KAPSARC, and also the CCS project lead at the World Resources Institute. He holds an M.P.A. from the Maxwell School of Syracuse University and a Ph.D. in Environmental Science from the State University of New York. Xiaoliang also holds a program certificate of carbon capture and storage: science, technology, and policy from Massachusetts Institute of Technology (MIT).

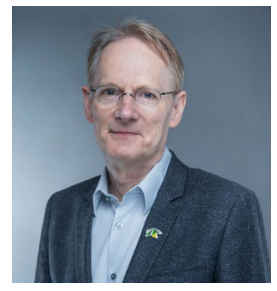

\section{Wolfgang Heidug}

Wolfgang is an expert on low-carbon energy technology policy with in-depth knowledge of the science and technology of $\mathrm{CO}_{2}$ capture and storage. Prior to joining KAPSARC he was a senior adviser at the International Energy Agency in Paris. Wolfgang has over 20 years' experience working with Shell International. He obtained his Ph.D. in Engineering from the U.S. and holds an M.S. in Physics and Economics from Germany.

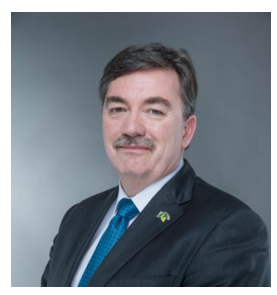

\section{Douglas Cooke}

Douglas is the former program director of the Energy Transitions and Environment program at KAPSARC. He is an experienced senior public policy practitioner with three decades of experience advising the Australian government. This included two decades leading and working on energy policy and regulation focusing on energy market reform, international energy dialogue and energy security.

\section{About the Project}

This project examines opportunities to apply carbon capture, use and storage technologies to reduce the net carbon content of oil, with a view to helping secure demand for Saudi oil in an increasingly carbon-constrained world. It assesses policy options and analyzes legal, regulatory and commercial issues affecting the development and deployment of these technologies. This reports provides insights on the Chinese CCS policy framework which may inform policymaking decisions in other countries. 
INAPSARC

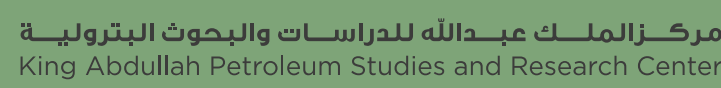

www.kapsarc.org 